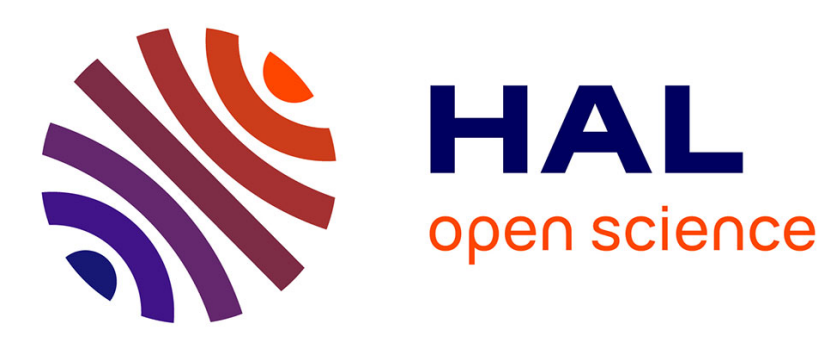

\title{
Paradox of the Pariah: Toward a Weberian Understanding of Modern Journalism
}

Gilles Bastin

\section{To cite this version:}

Gilles Bastin. Paradox of the Pariah: Toward a Weberian Understanding of Modern Journalism. Max Weber Studies, 2013, 13 (2), pp.216-236. halshs-00969557

\section{HAL Id: halshs-00969557 https://shs.hal.science/halshs-00969557}

Submitted on 8 Nov 2016

HAL is a multi-disciplinary open access archive for the deposit and dissemination of scientific research documents, whether they are published or not. The documents may come from teaching and research institutions in France or abroad, or from public or private research centers.
L'archive ouverte pluridisciplinaire HAL, est destinée au dépôt et à la diffusion de documents scientifiques de niveau recherche, publiés ou non, émanant des établissements d'enseignement et de recherche français ou étrangers, des laboratoires publics ou privés. 


\title{
Paradox of the Pariah
}

\section{Toward a Weberian Understanding of Modern Journalism}

Published in Max Weber Studies, 13 (2), p. 216-236, 2013

Preprint version. Please check the published version at http://connection.ebscohost.com/c/articles/92945255/paradox-pariah-toward-weberianunderstanding-modern-journalism

\author{
Gilles Bastin
}

Assistant Professor of Sociology

Institute of Political Studies, University of Grenoble (France)

gilles.bastin@iepg.fr 
Introduction

Max Weber's 1919 conference on the profession and vocation of politics (Politik als Beruf) is probably the best-known and most-read contribution of the German sociologist to the study of journalism. ${ }^{1}$ In this text Max Weber analysed the chances for different kinds of occupations to produce political leaders, as well as the requirements of an authentic vocation for politics. Stressing the fact that many at that time had entered journalism to embark on a political career, Weber referred to the journalist as 'the most important representative of the demagogic species ', a statement that was by no means intended as criticism (Weber 1946a: 96). As Weber noted, though, modern journalists were often unable to follow such a career, due to economic contingencies including 'lack of availability' (a consequence of the 'increased intensity and tempo of journalistic operations') and the necessity to work for a living at large industrialised firms (Weber 1946a: 97). The sociologist did not just depict the context in which journalists operated (the social and moral segregation they suffered from, and the absolute job insecurity they endured as a result of what he called the 'market'). He also highlighted the inner tensions caused by the contrast between this market-based insecurity and the widespread perception of the power of journalists. Weber concluded his presentation with words which were typical of the 'heroic asceticism' (Aron 1969) or 'aristocratic' (Mitzman 1970) posture that was familiar to him in the 1917-1919 conferences:

\footnotetext{
${ }^{1}$ A very first draft of this paper was presented in 2009 in Paris at a seminar organized at the Maison des Sciences de l'Homme in honour of Hinnerk Bruhns to whom I owe the knowledge that Max Weber's brighter ideas always can be turned into paradoxes. Isabelle Darmon gave me the opportunity to return to the 'pariah's paradox ' by inviting me to participate to a seminar organized in 2013 in Manchester on behalf of the British Sociological Association.
} 
'[Journalism] is not a road for everybody, least of all for weak characters, especially for people who can maintain their inner balance only with a secure status position.' (Weber 1946a: 98).

In this paper I intend to review the most important texts in which Weber dealt with modern journalism. My aim is to explore two 'aspects' of the condition of journalists according to Weber: their market situation and their ethical situation ('character' or 'personality'). I will argue that understanding journalism in Weberian terms requires close scrutiny of both sides, whereas most commentaries - including my own as explicated in previous papers (Bastin 2002, 2010) - have predominantly 'focused on Weber's analysis of the 'market' situation. To do so, I will use as a starting point an enigmatic comparison that Weber made in his 1919 conference on politics. Pointing out that journalists 'on the continent' lacked 'a fixed social classification' and that 'society' tended to estimate them 'in terms of [their] ethically lowest representatives', he compared journalists to a 'pariah caste' (Weber 1946a: 96). ${ }^{2}$ The use of this term to describe journalists is not something that would normally require complex explanations, as such comparisons were a trope among $19^{\text {th }}$ century European intellectuals. ${ }^{3}$ But Weber was a very informed sociologist of religions, including Hinduism. Most of his work-notably the strand of his work concerned with the rationalisation of the world, which in my view includes his sociology of the press (Bastin 2010), was thoroughly influenced by his so-called 'sociology of religion' (Bendix 1960; Tenbruck 1980). Moreover,

2 The German text is the following : 'Der Journalist teilt mit allen Demagogen und übrigens - wenigstens auf dem Kontinent und im Gegensatz zu den englischen und übrigens auch zu den früheren preußischen Zuständen - auch mit dem Advokaten (und dem Künstler) das Schicksal : der festen sozialen Klassifikation zu entbehren. Er gehört zu einer Art von Pariakaste, die in der "Gesellschaft" stets nach ihren ethisch tiefststehenden Repräsentanten sozial eingeschätzt wird.' (Weber 1958, : 513)

${ }^{3}$ In France for instance, the use of the word 'pariah' to describe journalists can be documented in novels like Le journaliste by Emile Souvestre (1839 vol. 1: 336) or Le lorgnon by the wife of Emile de Girardin, founder of La Presse, one of the first modern newspapers. This latter novel pictures the life of a young journalist describing himself as a 'pariah' in a conservative milieu after the 1830 uprising (1831: 227-8). 
Weber is known to have contributed to the development of an analogy between Hinduism and Judaism through the use of the category of the 'pariah people' (Pariah Gastvolk) to describe the forms of ritual segregation that Jews had encountered in most societies (Momigliano 1980; Raphael 1976). Thus it seems fair to assume that Weber didn't use the word 'pariah' to describe journalists in a haphazard fashion. ${ }^{4}$ The goal of this paper is to try and find out what this comparison means, and what direction a sociology of journalists-aspariahs might assume.

This inquiry into Weber's approach to journalism does not just have relevance for mere historical interest. Weber's interest in the press and journalism of his time was linked to the state of the news industry at the beginning of the 20th century. The growing readership of newspapers can be linked to the new divisions of labour among press workers and to the well-known depoliticized approach to news in that period. Many academic debates occurred regarding the evolution of journalism in Europe at the time. Sharp criticism of this 'new American' form of journalism was common among scholars in Germany, including Weber's own brother Alfred (Kalinowski 2005). Yet analysis of Weber's insights into journalism does not necessitate forgetting about the journalism of the present time. On the contrary, after decades of slow but regular improvement in the employment conditions of journalists in most countries, ${ }^{5}$ there are signs that at the beginning of the 21 st century, journalists may again be facing highly insecure employment conditions. These conditions include: in most media, a decrease in the number of journalists actually employed; the rise of freelance jobs (Baines, 1999); shrinkage of internal labour markets in the cultural, knowledge and media

\footnotetext{
4 The passage of the conference devoted to journalists was added only in the print version by Weber. He cannot therefore be suspected of not having chosen his words carefully.

${ }^{5}$ For a good overview of the changes between the 1920 s and the 1980 s, the comparison of the two surveys conducted by the International Labour Organization is a good starting point (ILO 1928; Bohère, 1984)
} 
sectors (Marsden, 2007); increase of the use of low-priced amateur talent (Flichy 2010; Leadbeater and Miller 2004; Van Dijck 2009); general low pay levels; widespread layoffs of workers in beginning or mid-career; and general career 'burn-out' (Reinardy 2011). As a result the professional organization of journalists has been undermined in most countries. At the same time, the rise of the field of public relations has changed working conditions for journalists. It has also opened up job opportunities outside the profession for mid/end-ofcareer journalists, even as changes in the educational background of journalists have resulted in the development of massive pools of qualified graduates who work as unpaid interns for long periods in order to launch their careers. As a result of these dramatic shifts in the media, the labour market for journalists—which Weber described as 'a gamble'-has recently been described as 'transitional' (Schmid 2002) and 'uncertain' (Pilmis 2008).

These trends in the labour market - as well as signs that the 'character' of journalists could also be changing due to factors such as adaptation to the use of networks (Antcliff, Saundry and Stuart 2007), 'personal branding', the spreading of a 'competitive ethos' between protagonists in the media worlds (Ehrlich 1995), and having to face a high level of distrust of the media from the publics—clearly indicate that a return to the Weberian perspective may be useful in understanding the new journalism that is emerging today.

\section{The paradox of the pariah in Weber's sociology}

Max Weber's use of the term 'pariah' in his 1919 conference was linked to his understanding of Hinduism and the Hindu caste system. Yet it can hardly be separated from his concept of the sociology of Judaism and the so-called 'Jewish question', which is a very complex and controversial issue, not only for Weberian scholarship (Abraham 1988; Love 2000; Schäfer- 
Lichtenberger 1991) but also more broadly (Arendt 1944). Weber's use of the term pariah was not informed by the original Hindu notion, which referred to the alleged impurity of these individuals, but was, as Weber reckoned in The Religion of India: The Sociology of Hinduism and Buddhism, based on a European and metaphorical idea of a 'guest people', who were socially segregated as a result of their outsider status (GARS II: 12). In 1904 Weber used the notion of 'pariah capitalism' (Paria Kapitalismus) in The Protestant Ethic and the 'Spirit' of Capitalism (Weber 1992: 166) to refer to the specificity of the contribution of Judaism to modern capitalism. For Weber, Jews did not play an important role in the development of capitalism, since they lacked the systematic asceticism that was characteristic of the Protestant ethic. Their form of economic activity was not industrial but financial, mostly due to their segregation from the dominant Christian society. In Economy and Society he defined a 'pariah people' as 'a distinctive hereditary social group lacking autonomous political organization and characterized by prohibitions against commensality and intermarriage'. He added that 'two additional traits of a pariah people were political and social disprivilege and a far-reaching distinctiveness in economic functioning' (1978: 493). The concept of 'pariah' thus clearly entailed a macro-social dimension. Pariahs, in the Weberian sense of the word, were people who had been turned into outcasts due to the various forms of segregation they suffered from (such as ritual, marriage-related, ethical or urban segregation) and the resulting loss of social identity produced by this segregation.

But Weber's analysis was not limited to the social status of 'pariahs' in a macro-social way. The very short introduction to Weber's Ancient Judaism (which was published between 1917 and 1919 in the Archiv für Sozialwissenschaft und Sozialpolitik, at the same time that Weber compared journalists to pariahs) can be read as a definition of the sociological concept of 
'pariah'. While segregation was an important feature of the pariah in this text, Weber specified that a) segregation could be formal or real; b) it could be chosen or imposed; and c) the existence of a caste system was not a necessity. In this text the greater focus was on religious convictions, such as Jews' belief in a forthcoming radical break with history (the realisation of the divine promise that all things would be reversed at the end) in contrast to the Hindu belief in the reproduction of society. Weber also stressed the ethical dimension of Judaism: a rational commitment to the world. The whole point made by Weber in Ancient Judaism was about the very strong inner conflict produced by living as a pariah, when it was coupled with strong religious convictions and a rational approach to salvation. Weber carefully analysed the different ways that Jews found to solve this inner conflict. For some Jews, this was found through strict ritualism, which served to firmly separate the divine from the terrestrial, or, at the opposite end, the ecstatic prophecies of the 'prophets of doom' and the theodicies of suffering they expressed (Weber 1952: 3-5).

The complexities of Weber's analysis cannot be rendered here. What matters in our attempt to elucidate the sociological meaning of 'pariah', is Weber's idea that individuals living as a pariah experienced a strong tension between their social status and their 'convictions' (Gesinnung). Hence 'life conduct' (Lebensführung) cannot be derived from those external conditions, or from religious beliefs or theories. ${ }^{6}$ It is only the encounter of the two that produces meaningful consequences, through the behaviour of those who are the carriers of a religious conception of the world. As far as the Jewish metaphorical pariahs were concerned, these tensions produced a paradoxical commitment to the world and a 'factual' (Sachlich)

\footnotetext{
${ }^{6}$ See the second $\S$ of Weber's Introduction to the Economic Ethic of World Religions in which he stresses his lack of interest for ethics as theory but explains that he will place the emphasis on the 'practical impulses for action that are grounded in the psychological and pragmatic contexts of religions' (Weber 2004: 56).
} 
ethic that helped them to break with tradition. While social segregation, ritualism and the kind of religious virtuosity preached by the 'prophets of doom' might have been expected to marginalize the Jewish people during the development of humankind, and to play no role in the rise of western rationalism or the demagification process ('Entzauberung der Welt', usually translated as 'disenchantment of the world') that Weber presented as the central question in the famous 'Intermediate Reflection', the contrary happened. Even the Jewish prophets, who were the object of two segregation processes (as mad individuals within a segregated people), paradoxically played a very important role in the history of rationalization..$^{7}$ At this point we propose to use the very common figure of the paradox (Symonds and Pudsey 2008) to stress the importance of the pariah in the Weberian rationalisation of the world. The paradox of the pariah is two-dimensional. On the first level, it expresses the fact that individuals cannot be completely described by their social status, and may develop ethical convictions that help them behave in contradiction with this status. Social segregation may serve to reinforce rather than reduce the ethical convictions of those segregated, at least for the most 'virtuoso' among them, and this may assist pariahs in maintaining their calling. ${ }^{8}$ Job, the wealthy religious man tested by God in the Bible, provides an illustration of this paradox. He is the pariah par excellence for Weber (Kalinowski 2010: 46). Job's faith prevents him from losing his 'inner balance' in the face of suffering, and keeps him from blaming God as his friends advise him to do. He is steady in his calling and does not deviate from it, or lament his fate. The Weberian pariahs-i.e. the authentic or virtuoso pariahs, such as Job - are able to maintain their inner balance and their commitment to everyday this-worldly life, despite all signs that they will never find the answer to all their

\footnotetext{
${ }^{7}$ See the first pages of Ancient Judaism, in which Weber proposes that the missionary dimension of Christianity was fully inherited from the Jewish prophets (Weber 1958).

${ }^{8}$ Weber also noted that the Puritan's ascetic behaviour entailed a form of separation from the others.
} 
questions, and despite their prevailing feeling of the irrationality of the world (which is often an outcome of deprived social status). More than as a social or religious designation, the pariah appears as a specific human type that can be motivationally characterised by a high degree of 'inner distance', defined as

'a self-conscious adherence to certain ethical values, in the face of the immense daily pressures to conform to a rationalized and disenchanted world, and a degree of self-mastery that resists loss of "personality" under the relentless pressure of the demands of routine' (Schroeder 1991: 62).

On a second level, the paradox of the pariah expresses the fact that pariahs-in part due to their separation from the rest of society-can play a very important role in the demagification of the world. Because they develop very strong convictions in reaction to their separation from the rest of society, through personal suffering, an outcast can contribute to the discovery of the meaning of our actions. The experience of being socially segregated can lead to doubt, and to questioning the world as it seems to be, and to becoming one of Archimedes' levers (Kalinowski 2010: 48-49). The 'need for the rational' does not arise from existence within an opulent and protected social status, but rather from being confronted to an unjust society and the daily experience of personal limitation. Hannah Arendt particularly stressed this dimension of the Weberian pariah when she insisted on the rebellious nature of what she calls 'conscious' pariahs, as opposed to their counterparts, the Jewish parvenus (Arendt 1944; Denamy 1999; Löwy 2009).

The paradox of the pariah is an invitation to consider the 'tensions' (Lallement 2013) that every human being has to face between their 'external' (meaning socially conditioned) and 
'inner' (meaning psychologically conditioned) interests. ${ }^{9}$ The notion of pariahs has thus to do with Weber's concept of 'personality', a concept that is central to Weber's understanding of the way that ethical convictions (Gesinnung) are transformed into action principles, and a life conduct (Lebensführung) that helps the individual claim his singularity in a routinized world. ${ }^{10}$ This concept is among the most neglected (and usually poorly and unsystematically translated) Weberian notions. ${ }^{11}$ It is only because of the usual scholarly focus on Economy and Society and Weber's most systematic theoretical writings that such concepts have been underestimated. Personality is at the heart of Weber's analysis, because in his 'anthropocentric' (Kalberg 1994) or 'characterological' (Hennis 1988) approach (see the Wissenschaftslehre), ideas matter only if men and women are capable of transforming them into convictions and life principles. Commenting on the lost conference that Weber gave in September 1917 in Lauenstein a few weeks before his conference on science ('Personality and the life orders'), Hennis stated that the historical specificity of capitalism, according to Weber, tied personality and profession closely together through the notion of Beruf (see Weber's reply to Rachfahl where he explains that Puritanism conceives of profession and vocation as being at one with 'the innermost ethical core of the personality' (Weber 2002: 313) The 'shell as hard as steel'/'iron cage' theme can thus be interpreted as the moment when personality and profession diverge. In a 'depersonalized' world, then, convictions are

\footnotetext{
${ }^{9}$ The dialectic of 'inner' and 'external' interests is central in Weber's introduction to his series of articles on world religions ('Die Wirtschaftsethik der Weltreligionen', translated as 'The Social Psychology of the World Religions' in Gerth and Mills volume). See for instance Weber's remark that 'The interest situation of these strata, as determined socially and pyschologically, has made for their peculiarity, as we here understand it.' (Weber 1946b: 281). The german text is more explicit and mentions: 'die äußere, sozial, und die innere, psychologisch, bedingte Interessenlage derjenigen Schichten' (Weber 1986: 252).

${ }^{10}$ Weber had no interest in psychology as a scientific discipline (see for instance his criticism on the psychological foundations of economics); the concept of 'personality' is thus pragmatically and not psychologically defined. It refers to social image, not to a mysterious and idiosyncratic self. Confronted to the same problems, the historians of science Daston and Galison preferred the concept of 'persona' (Daston and Galison 2007).

${ }^{11}$ For an overview of translation issues in France, see Grossein $(1999 ; 2002 ; 2005)$.
} 
transformed into mere 'tuning' (Eingestelltheit) to adaptation (Darmon, 2011). See Hennis : 'Quelles sont les conséquences pour 'l'humanité' si les ordres rationalisés de la vie quotidienne ne permettent plus cette coordination [entre profession et personalité]? Je pense que c'est cela la question capitale que Weber a posée au monde où nous sommes jetés, à la suite de Marx.' (Hennis, 1996, p. 114) [trouver l'original dans (Hennis, 1987)].

Of course, this concept of personality is underpinned by a value standpoint. Weber sees personality as a response to the ontological insecurity that the demagification of the world produces in modern societies. Weber had only distrust for the kind of response offered by churches, states, political parties or even poetry (Löwith 2002). In contrast to these inadequate responses, in the 1917-1919 conferences Weber stated that men must confront the ethical multidimensionality of the world by organizing their lives to help them mature and commit to a cause, which would become their own, and devoting themselves to specialized work in the place of former Faustian omnicompetence (Schluchter 1996: 36-38). This, of course, often involves some form of separation from others (and possibly accepting treatment as a pariah) as well as difficult ethical choices for the scientist, the politician, or the journalist.

II. Anonymity and personality in journalism: the issue of bylines

If journalists are understood as Weberian metaphorical pariahs, this requires close scrutiny of their social status and working conditions on the one hand; and of their 'personality' and 'life conduct' on the other. As has been mentioned above, the 1919 conference on politics contained much acute insight into the 'external interests' that govern journalism. This is not surprising. Weber had a direct knowledge of journalism as a practitioner of the German 
media of his time (see his editorial writings for the Frankfurter Zeitung) and as an intellectual who did not hesitate to engage in disputes and lawsuits with 'revolver' journalists (as he called them) on issues concerning his wife and himself (Obst 1986). But the origins of Weber's sociological interest in the media are to be found in his plans for advanced research on journalism and the press, which he initiated around 1910 (the Preß-Enquête as he called it). These research interests are documented in Weber's oral contribution to the first meeting of the German Sociological Association in 1910 (Geschäftsbericht auf dem ersten deutschen Soziologentage) and the very much underestimated (and barely known) 'Preliminary Report on a Proposed Survey for a Sociology of the Press' (Vorbericht über eine vorgeschlagene Erhebung über die Soziologie des Zeitungswesen) that he had previously presented to his colleagues (Bastin 2002; Weischenberg 2012). ${ }^{12}$ Contrary to other scholars (like Tarde for instance in France, and Tönnies a bit later in Germany ${ }^{13}$ ), Weber's research plan demonstrated that he was less interested in the press as a political power that was capable of influencing opinion (a point of view that restricts analysis to the political role of the press) than as an industry that can control the collection and organization of news by journalists on one hand, and exercising an influence on society through the education of the mind, the 'enrichment and schematization of thought' for readers on the other (1998: 119).

This approach was organized around the issue of the 'anonymity' of the media (Bastin 2010). In the kind of economic and cultural historical approach to capitalism that prevails in the 'Preß-Enquête', 'anonymity' refers to two distinct processes: first, the use of 'anonymous ' (meaning industrialized and depoliticized) news (for instance in the 'GeneralAnzeiger' kind

\footnotetext{
12 This text has attracted only few commentaries, most of them focused on its methodological dimension (e.g. see Lazarsfeld et Oberschall 1965). Wilhelm Hennis was the first scholar to have reassessed the press project as a key document to understand Weber's central question. See Hennis 1987, 1998, 2000).

${ }^{13}$ See for instance his Kritik der Öffentlichen Meinung (Tönnies: 1922)
} 
of press, a forerunner of the contemporary free daily press). Weber used the concept of 'anonymity of articles' in the Vorbericht to describe the way in which newspapers produced homogeneity in their content. He also extended the concept to the whole newspaper as an organization; in section B on the Zeitungsgesinnung he referred to the 'anonymity of the newspaper', the process of producing a collective spirit that was not dependent on individual journalists. Of course the first element of this anonymity of the newspaper is the fact that most articles are published without a byline. Another one is the frequent use of anonymous sources within the articles. Weber also referred to the 'principle of anonymity' (Anonymitätsprinzip) in his lecture on politics ['principled anonymity' in the 1946 American edition] as a habit of the German press. When examined as an element of the 'external interests' of the journalist's (and the reader's) condition, the anonymity of contents had two aspects: on the one hand, it was a condition of modern rationalist development, and, in Weber's words, this contributed to the 'enrichment and schematizing of thought' and to 'widening the intellectual horizon'. Thus, during his course on economic history in Munich in 1920 , Weber mentioned that the organization of news was essential to the development of trade and for financial markets (1961: 220). On the other hand, it is also a factor of petrification leading to individual alienation. This is particularly apparent at the end of the Vorbericht; according to Weber, the press had a 'globalising, uniformising and reifying'14 influence on modern culture; a theme that would later be developed by critical thinkers.

If we now look at the 'internal interests', a question that was more important in the 1919 conference, the concept of anonymity referred to issues of personal ethics versus the promotion of newspaper sales by use of 'especially hired personages and talented writers

${ }^{14}$ Note of the editors: 'ubiquisierender, uniformierender, versachlichender' - Keith Tribe's translation differs: ubiquitous, standardizing, matter-of-fact (Weber 1998: 119). 
who always expressly figured under their names ' (Weber 1946a: 98). The starting point for these texts was that tensions arise in the press between the pressure toward anonymity (as a necessity of the newspapers' business organization) and toward personification of the contents (for commercial reasons, meaning the need to attract readers with famous names).15 Although Weber had already noted this tension in 1910 (he had mentioned the need for "attractive" names among the workers on a newspaper and the limits to this determined by the interests of the newspaper' - Weber 1998: 114), it was the central element of his later reflection. Weber did not really document this tension. He was more concerned with highlighting the ethical dilemma faced by modern journalism. Adopting the principle of anonymity was of course a necessity for the industrialized newspaper but it also gave birth to a commercial press (here defined as newspapers based on advertising and not readership revenue) that was 'the breeder of political indifference' (Weber 1946a: 97). Rejection of this principle-as some newspapers had started to do during the warcould lead either to the 'irresponsible sensationalism' that ensued when publishers and journalists preferred earning fortunes to preserving their honour (1946a: 98), or to the reverse situation if making a name in journalism ('accomplishing' oneself as Weber says) could be correlated with all the moral virtues Weber associated with journalists, such as 'genuine men', 'discretion', 'honour', 'responsibility', 'dignity', etc. Weber's personal stance is easy to elucidate. His personal disdain for journalists who used anonymous sources and did not sign their articles was well known, following his successful involvement in the two libel cases that he initiated in 1911-13 against a Heidelberg Privatdozent and a journalist from the Dresdener Neuesten Nachrichten (Obst 1986). His criticism of the bureaucratization of

\footnotetext{
15 These tensions very much resemble those opposing 'plunder capitalism' and 'everyday rational management in large capitalist firms' in Max Weber's analysis of the 'double nature of the spirit of capitalism and the tension between charisma and everyday life in the economy’ (1972: 659; 1978: 1118, translation altered).
} 
political communication was also documented in another text written in 1917 and published in the Frankfurter Zeitung: 'Parliament and Government in a reorganized Germany'. In this text Weber mentioned the fact that, due to the bureaucratizing of politics, 'non-accountable authorities' tend to communicate directly with the public, and in so doing, bypass political leaders (Weber notably referred to the way that the German bureaucracy managed Wilhelm Il's declarations to the press). Weber criticized the use of 'anonymous' materials in the media and in politics, and was of the view that the authentic journalist and politician should resist this in order to maintain a vivid and responsible public sphere.

Finally, Weber's portrait of the responsible journalist in 'Politics as a Vocation and Profession' clearly indicated that granting the journalist a chance to base his or her 'occupational destiny' on his/her own qualities and thus on his/her name was unlikely, given the pressures on newspapers and their 'lead on the feet' effects on journalists and would-be politicians. Yet Weber prized these journalistic 'accomplishments' even more than scholarly ones. This was what mattered to Weber:

'The journalist's life is an absolute gamble in every respect and under conditions that test one's inner security in a way that scarcely occurs in any other situation. The often bitter experiences in occupational life are perhaps not even the worst. The inner demands that are directed precisely at the successful journalist are especially difficult.' (Weber 1946a: 98).

Understanding journalists-as-pariahs thus draws more attention to the inner tensions produced by their employment and working conditions as well as on their ability to sustain 
personality in an increasingly anonymized world (what Weber calls their 'occupational destiny '). ${ }^{16}$

It was a very typical feature of Weber's conferences that external interests were expressed as facts whereas internal ones remained in the field of ethical choice. This does not mean, though, that the question of the personality of the journalist in the face of press anonymity should be viewed as purely speculative. The issue of the 'personality' of the journalist wasand still is-a very central one in modern culture. This has been documented in numerous essays, novels and dramas describing journalists as starving penny-a-liners, broken down scholars or failed poets. The question of the 'inner balance' of such characters is indeed a very interesting playground for novelists, playwrights (Schmock, Bel Ami), philosophers (from Voltaire to Kraus) and movie directors (from Capra to Pakula) wishing to describe social pathology including intellectual misery, unlimited political ambition, ethical uncertainty and various forms of corruption. This cultural context contributed to the production of a social imagery of the journalist-as-pariah, and also attracted individuals who saw journalism as a first step toward something, thus reinforcing the 'gamble' nature of occupational careers in journalism.

The issue of bylines has attracted less attention among journalism scholars than other issues such as the question of objectivity. Yet it had already been vividly debated in the 19th century, and is very meaningful to a Weberian sociology of journalism. For instance, Karl

\footnotetext{
${ }^{16}$ There is another 'tension' worth mentioning in this text: the tension between the journalist's self-image and the social imagery of the journalist. Weber interestingly notes that, as opposed to other professions, journalists are only estimated 'in terms of [their] ethically lowest representative'. He also notes that 'in the very nature of the case, irresponsible journalistic accomplishments and their often terrible effects are remembered. Nobody believes that the discretion of any able journalist ranks above the average of other people, and yet that is the case. The quite incomparably graver temptations, and the other conditions that accompany journalistic work at the present time, produce those results which have conditioned the public to regard the press with a mixture of disdain and pitiful cowardice.' (1946: 96).
} 
Marx is known to have considered bylines as a victory of commercial news vs. the newspaper as a collective body (see his articles in the Neue Rheinische Zeitung). This position was shared at approximately the same time (but for different reasons) by Adolph Ochs, the founder of the New York Times, who established anonymity as a principle according to which 'the newspaper as a business must be absolutely impersonal'. ${ }^{17}$ Conversely, Emile Zola expressed his preference for bylines in 1893 at the London Institute of Journalism, stating that the practice allowed journalists to display their talent under their own names rather than trying to stick to the opinion of the readers (proceedings of the conference published in le Figaro on 22 September 1893, first page). Zola expressed a liberal conception of the need for individual voices: 'Sans doute chacun de ces grands talents se bat pour lui; mais il n'en fait pas moins la lumière pour tous' (Bautier and Cazenave 2001 : 93). ${ }^{18}$

Weber captured the issue of the personality of journalists early in the debate on this issue. In most countries, bylines were a rarity during beginning of the history of printed news, but this began to change in the $1920 \mathrm{~s}^{19}$ As Schudson has shown using the archives of the front pages of the NYT as reference, the use of anonymous pieces in the press started to diminish in the 1920s; by 1944 almost every article (as well as Associated Press stories) was credited with a byline (Schudson 1978). ${ }^{20}$ The issue of bylines continued to be important in

\footnotetext{
${ }^{17}$ This was also practiced by Bunau-Varilla, the owner of Le Matin in Paris, who was a former construction-and public works-entrepreneur and is known to have declared that 'au Matin il n'y a pas de journalistes, il n'y a que des employés'. Journalists working for Le Matin were given pennames from railway stations like Jean d'Orsay, Robert Bures or Pierre Limours)

18 An interesting summary of the debates that occurred in the years 1880 to 1910 on this issue can be found in Shafer (2006).

${ }^{19}$ The periodization is subject to debate. See Reich (2010). Of course local contexts also matter. In France, bylines were made compulsory for political reasons in 1850 (Brunet 1989; Feyel 2001). See also Reich and Boudana 2013.

20 The word 'byline' is supposed to have entered the Oxford English Dictionary following the publication of The Sun also Rises by Hemingway (1926): 'He sat in the outer room and read the papers, and the Editor and Publisher and I worked hard for two hours. Then I sorted out the carbons, stamped on a byline, put the stuff in a couple of big manila envelopes and rang for a boy to take them to the Gare St. Lazare.'
} 
journalism until the 1960s when the 'new journalism ' reclaimed even more authorship for individual journalists (see T. Wolfe's 'very few editorial employees at the bottom-namely the reporters-had any ambition to move up, to become city editors, managing editors, editors-in-chief [...] Reporters didn't want much ... merely to be stars!' (cited by Hollowell 1977: 50 see also Reich: 2010).21

The evolution towards the increased use of bylines in the history of news can be analyzed following Weber's approach. This evolution provided more responsibility to the journalist, while creating incentives to use that responsibility to promote the journalist as a name (whether this meant good journalism or sensationalism). This means a diminution of the inner tension that is included with pariah status, and thus more possibilities to express one's personality and to build a career in journalism. As a consequence, names started to be seen in the media as resources that could be used by journalists in their fight to secure their public personalities. Deontological texts for instance started to grant the right of reporters to remove their names from contents that they did agree with. Social movements known as 'byline strikes' (as in 1978 at the NY Post) proved that names were seen as key assets for journalists and journalists, 'personality' a collective right to fight for.

This necessarily brought changes in the 'external interests' of journalism. It is worth noting that the professional context of journalism evolved in congruence with the evolution of bylines. The professionalization process made questions about the personality of the individual journalist less important: collective institutions were emerging (unions-in France in 1918, the NUJ in the 1930's); legal protections (1935 in France: limited the pressures from the industry by granting a 'clause de conscience' and source protection);

${ }^{21}$ The excitement felt when reading their own name in the newspaper is a commonplace of journalists' biographies. 
training (that helped journalists define good and bad practices ${ }^{22}$ ); professional codes (see the very interesting first line of the French code of conduct in 1918: a true journalist 'takes responsibility' for his articles, even if not signed! A similar code was adopted in the United Kingdom in 1936 23 ); and even some economic advantages (see the specific tax system in France). Journalists started to be better protected from 'the market' (as Weber says). Even the public image of the journalist began to change through the massive investment by Hollywood in the creation of a new body of positive journalistic myths, which culminated in the 1970s.

It is a very interesting feature of contemporary journalism that many fear that the byline could disappear from the media, especially on the web (Groves 2007). Some recent cases illustrate new trends, such as the use of pen-names (some ironically taken from Hemingway's novel) by Filipino contributors to the 'content farm' Journatic, a content provider to major US newspapers and websites, or a similar case of content that was produced by anonymous journalists in Tunisia and printed in local French newspapers. Changes in the labour market for journalists impact their ability to retain a name and personality. Instead of being granted to every journalist as a collective right, the byline may begin to follow a more selective pattern, as already occurred for TV in the 1970s, and in newspapers where distinctions were made between ordinary and 'star' journalists (Reich and Boudana 2013). Due to columnization of news in a lot of major newspapers, some journalists were granted more control over their content (for instance by having their picture, or an e-mail address next to their byline). At the same time that some journalists

\footnotetext{
22 See the idea that puritans have 'ethical training ' in The Protestant Ethic.

${ }_{23}$ 'A journalist has the right to refuse an assignment or be identified as the author of editorial that would break the letter or spirit of the code'.
} 
strive for recognition, others may return to the old 'anonymity principle'. This would result in a sort of two-tier life chance system, in which some enter a highly insecure individual career path where keeping a journalistic name is the key to success (thus increasing the 'tensions' for individuals), while others return to the old status of anonymous pariah. This can be perceived as a regression to the tensions that journalists faced when Weber wrote his research proposal on the press, and as a situation in which, as in the culture and sports economy in general (Rosen 1981; Rosen and Sanderson 2001), a minority ends up monopolizing the bulk of available monetary and non-monetary resources.

\section{Conclusion}

Despite some remarkable attempts, such as by Hennis, Max Weber's approach to the media and journalists of his time has not yet really been taken seriously by scholars, either in media studies nor in Weberian scholarship. Social studies of the media have long looked down upon the media world and showed a clear penchant for theorising and-when empirical research was conducted-for a narrow focus on the issue of political influence. Questions regarding the political economy of information and the conditions of production of media content have been systematically avoided in the years following Weber's own attempt at sociology of journalism (Gans 1972; Janowitz and Schulze 1961). A large number of research studies have since filled this gap. However, the issues of the personality and market positioning of journalists have still received only limited attention in comparison with other issues such as source-journalists relations or the sociology of the professional journalist associations. ${ }^{24}$ Research has focused more on work settings and groups than on individuals as 'information

${ }^{24}$ It is ironical that a great deal of the literature on professional power has been labelled 'neo-Weberian' but only studies the 'external ' side of the professional condition. 
workers' (Hardt and Brennen 1995) or more generally on the individuals who 'carry out' the activity of journalist (Dickinson 2007) and their working or career-plan conditions (Bastin 2013b; Örnebring 2010).

One reason for the relative failure of the Weberian perspective on journalism is to be found in its ethical/normative dimension. The 1919 conference notably revealed Weber's 'romantic' posture (Löwy 2013) that journalists—as, in their own domain, entrepreneurs, politicians or scientists-may contribute to the petrification of our social and economic 'cosmos ' and its 'anonymization' but also that, should they really stick to their vocation and not fear being turned into pariahs, they may succeed in resisting the pressures of routinization, bureaucratization and reification. Weber's analysis of the fate of the journalist makes sense for us because it is connected to the 'shell as hard as steel'/'iron cage' issue, one of the most powerful sociological concepts and metaphors ever introduced to sociology (Baehr 2001; Tiryakian 1981). Of course, such an ethical position comes with the risk that scholars involved in empirical research will find it intimidating and discard it.

If we wish to describe the journalist-as-pariah in a Weberian manner, we should focus on his 'personality' in the most pragmatic way. The history of bylines is of course one of these ways. Others can be constructed through studies on journalist careers. Indeed, as the volume of full-time jobs in the news sector declines in the vast majority of democratic countries while the use of freelance journalists spreads, the issue of insecurity in the lives and careers of journalists has again taken centre stage. 'Social worlds' (including the media) are characterised by a varying ability to 'attract' and retain professional talent (Strauss 1978). Understanding what attracts individuals to journalism and how they join the media labour market as well as what pushes them away from it is key to the issue of the 'personality' of 
journalists. Since divergence phenomena (Bastin 2013a) can end up distancing them from the central activity of the media worlds, questions arise such as the continuity of these social worlds; the socialisation of young recruits in organisations which lose their oldest employees due to divergence patterns (Grugulis and Stoyanova 2011); and the quality of production under these conditions.

Studying journalism in a Weberian manner means finding ways of describing not only the social and economic environment of journalism, but also the ways in which it contributes to the production of a journalistic 'personality' and thus to the life chances of those who want to embrace this vocation. This matters for democracy, but also for a renewed sociology of journalism. 
Bibliography

1928 Conditions of work and life of journalists, Geneva: International Labour Organization.

Abraham, G.

1988 'Max Weber on "Jewish Rationalism" and the Jewish Question'. International Journal of Politics, Culture, and Society 1 (3): 358-391.

Antcliff, V., Saundry R. and Stuart M.

2007 'Networks and social capital in the UK television industry: The weakness of weak ties'. Human Relations 60 (2): 371-393.

Arendt, $\mathrm{H}$.

1944 'The Jew as pariah: a hidden tradition'. Jewish Social Studies, 6 (2): 99-122.

Aron, R.

1969 La philosophie critique de l'histoire. Essai sur une théorie allemande de l'histoire Paris : Librairie philosophique J. Vrin.

Baehr, P.

2001 "The "iron cage" and the "shell as hard as steel": Parsons, Weber, and the Stahlhartes Gehäuse metaphor in the Protestant ethic and the spirit of capitalism', History and Theory 40 (2): 153-169.

Baines, S. 
1999 'Servicing the Media: Freelancing, Teleworking and “Enterprising” Careers', New Technology, Work and Employment, 14 (1): 18-31.

Bastin, G.

2002 'La presse au miroir du capitalisme. Une enquête de Max Weber sur les journaux et le journalisme', Réseaux, 109 : 172-208.

2010 'The mediatisation and anonymisation of the world in the work of Max Weber', Max Weber Studies, 9 (1\&2): 123-141.

2013a 'Gravitation, aléa, séquence. Variations sociologiques autour du concept de carrière', in Didier Demazière et Morgan Jouvenet (Eds.), La sociologie d'Andrew Abbott, To be published.

2013b. 'Newsworkers and their gendered careers', Textual and Visual Media, 5:17-30.

Bautier, R. and Cazenave E.

2001 'Anonymat et espace public au xix ème siècle', in Lambert F. (ed.), Figures de l'anonymat: médias et société (Paris : L'Harmattan) : 83-93.

Bendix, R.

1960 Max Weber. An Intellectual Portrait, New York:Anchor Books.

Bohère, G.

1984 Profession: Journalist. A Study on the working conditions of journalists, Geneva: International Labour organization. 
Brunet, M.

1989 'Anonymat et pseudonymat au XIXe siècle: l'envers et l'endroit de pratiques institutionnelles', Voix et images, 14 (2) : 168-182.

Darmon, I.

2011 'No 'new spirit'? Max Weber's account of the dynamic of contemporary capitalism through'pure adaptation'and the shaping of adequate subjects', Max Weber Studies, 11 (2): 193-216.

Daston, L. J. and Galison P.

2007 Objectivity, Cambridge (Mass.) : MIT Press.

Denamy, S. C.

1999 Le souci du monde: dialogue entre Hannah Arendt et quelques-uns de ses contemporains, Adorno, Buber, Celan, Heidegger, Horkheimer, Jaspers, Jonas, Klemperer, Levi, Levinas, Steiner, Stern-Anders, Strauss, Voegelin, Paris: Vrin.

Dickinson, R.

2007 'Accomplishing Journalism: Towards a Revived Sociology of a Media Occupation', Cultural Sociology, 1 (2): 189-208.

Ehrlich, M.C.

1995 'The competitive ethos in television newswork', Critical Studies in Media Communication, 12 (2): 196-212. 
Feyel, G.

2001 'La querelle de l'anonymat des journalistes, entre 1836 et 1850', in Lambert F. (ed.), Figures de l'anonymat: médias et société (Paris : L'Harmattan) : 27-55.

Flichy, P.

2010 Le sacre de l'amateur, Paris : Seuil.

Gans, $\mathrm{H}$.

1972 'The Famine in American Mass-Communications Research : Comments on Hirsch, Tuchman, and Gecas', American journal of sociology, 77 (4): 697-705.

Grossein, J.-P.

1999 'Peut-on lire en Français l'Éthique protestante et l'esprit du capitalisme?', Archives européennes de sociologie, XL (1): 125-147.

2002 'À propos d'une nouvelle traduction de l'Éthique protestante et l'esprit du capitalisme', Revue française de sociologie, 43 (4): 653-671.

2005 'De l'interprétation de quelques concepts wébériens', Revue française de sociologie, 46 (4): 685-721.

Groves, E.

2007 'Bye-Bye Byline', American Journalism Review, April-May.

Grugulis, I. and Stoyanova D. 
2011 'The missing middle: communities of practice in a freelance labour market', Work, employment \& society, 25 (2): 342-351.

Hardt, H. and Brennen B.

1995 Newsworkers: Toward a History of the Rank and File, Minneapolis: University of Minnesota Press.

Hennis, W.

1987 Max Webers Fragestellung, Tübingen: Mohr.

1988 Max Weber: essays in reconstruction, London: Allen \& Unwin.

1996 La problématique de Max Weber, Paris : Presses Universitaires de France.

1998 'The Media as a cultural problem: Max Weber's sociology of the press', History of the Human Sciences, 11 (2): 107-110.

Janowitz, M. and Schulze R.

1961 'Tendances de la recherche dans le domaine des communications de masse', Communications, 1 (1) : 16-37.

Kalberg, S.

1994 Max Weber's comparative-historical sociology, Chicago (Ill.): University of Chicago Press.

Kalinowski, I.

2005 Leçons wébériennes sur la science \& la propagande, Marseille : Agone. 
2010) 'Introduction', in Max Weber (Ed.) Le judaïsme antique (Paris : Flammarion) : 7-61.

Lallement, M.

2013 Tensions majeures: Max Weber, l'économie, l'érotisme, Paris : Gallimard.

Lazarsfeld, P. F. and Oberschall A. R.

1965 'Max Weber and empirical social research', American Sociological Review, 30 (2): 185-199.

Leadbeater, C. and Miller P.

2004 The Pro-Am Revolution: How enthusiasts are changing our economy and society, London: Demos.

Love, J.

2000 'Max Weber's Ancient Judaism', in Stephen Turner (ed.) The Cambridge Companion to Weber, Cambridge (UK): Cambridge University Press.

Lowith, K.

2002 Max Weber and Karl Marx, London: Routledge.

Löwy, M.

2009 'Le concept de 'pariah conscient ' chez Hannah Arendt, et le cas des intellectuels juifs d'Europe centrale', Loxias, 24.

2013 La cage d'acier. Max Weber et le marxisme wébérien, Paris : Hachette. 
Marsden, D.

2007 Labour market segmentation in Britain: the decline of occupational labour markets and the spread of 'entry tournaments', London: London School of Economics and Political Science.

Mitzman, A.

1970 The iron cage: An historical interpretation of Max Weber, New York: Transaction Books.

Momigliano, A.

1980 'A note on Max Weber's definition of Judaism as a Pariah-Religion', History and Theory, 19 (3): 313-318.

Obst, B.

1986 'Das Ende der Presse-Enquete Max Webers. Der Heidelberger Professorenprozeß von 1912 und seine Auswirkungen auf die deutsche Zeitungswissenschaft ', in vom Bruch R. and Roegele O. B. (eds.), Von der Zeitungskunde zur Publizistik. Biographisch-institutionelle Stationen der deutschen Zeitungswissenschaft in der ersten Hälfte des 20. Jahrhunderts (Frankfurt am Main: Haag+Herchen Verlag): 4562.

Örnebring, $\mathrm{H}$.

2010 'Technology and journalism-as-labour: Historical perspectives', Journalism, 11 (1): $57-74$. 
Pilmis, 0.

2008 L'organisation de marchés incertains. Sociologie économique de la pige et de l'art dramatique, Paris : EHESS.

Raphael, F.

1976 'Les Juifs en tant que peuple pariah dans I'œuvre de Max Weber', Social Compass, 23 (4) : 397-426.

Reich, Z.

2010 'Constrained authors: Bylines and authorship in news reporting', Journalism, 11 (6): 707-725.

Reich, Z. and Boudana S.

2013 'The fickle forerunner: The rise of bylines and authorship in the French press', Journalism, to be published.

Reinardy, S.

2011 'Newspaper journalism in crisis: Burnout on the rise, eroding young journalists' career commitment', Journalism, 12 (1): 33-50.

Rosen, S.

1981 'The economics of superstars', The American economic review, pp. 845-858.

Rosen, S. and Sanderson A.

2001 'Labor markets in professional sports', The Economic Journal, 111(469): 47-68. 
Schäfer-Lichtenberger, C.

1991 'The Pariah: Some Thoughts on the Genesis and Presuppositions of Max Weber's Ancient Judaism', Journal for the Study of the Old Testament, 51: 85-113.

Schluchter, W.

1996 Paradoxes of modernity: Culture and conduct in the theory of Max Weber, Stanford (Cal.): Stanford University Press.

Schmid, G.

2002 'Towards a theory of transitional labour markets', in Günther Schmid et Bernard Gazier (eds.), The dynamics of full employment. Social integration through transitional labour markets (Cheltenham \& Northampton (Mass.): Edward Elgar): 151-195.

Schroeder, R.

1991 'Personality' and 'inner distance' : the conception of the individual in Max Weber's sociology', History of the Human Sciences, 4 (1): 61-78.

Schudson, M.

1978 Discovering the News. A Social History of American Newspapers, New York: Basic Books.

Shafer, J.

2006 How the byline beast was born, Opinions. Reuters. 
Strauss, A.

1978 'A social worlds perspective', Studies in symbolic interaction, 1: 119-128.

Symonds, M. and Pudsey J.

2008 'The Concept of 'Paradox' in the Work of Max Weber', Sociology, 42 (2): 223-241.

Tenbruck, F. H.

1980 'The problem of thematic unity in the works of Max Weber', The British Journal of Sociology, 31 (3): 316-351.

Tiryakian, E.

1981 'The Sociological Import of a Metaphor : Tracking the Source of Max Webers's "Iron Cage" ', Sociological Inquiry, 51 (1): 27-33.

Tönnies F.

1922 Kritik der Öffentlichen Meinung, Berlin: Julius Springer Verlag.

Van Dijck, J.

2009 'Users like you? Theorizing agency in user-generated content', Media, culture, and society, 31 (1), p. 41-58.

Weber, M.

1946a 'Politics as a Vocation ', in H. H. Gerth and C. Wright Mills (ed.) From Max Weber. Essays in Sociology (New York: Oxford University Press): 77-128. 
1946b "The Social Psychology of the World Religions" in H. H. Gerth and C. Wright Mills (ed.) From Max Weber. Essays in Sociology (New York: Oxford University Press): 267301.

1952 Ancient Judaïsm. Translated and edited by Hans H. Gerth and Don Martindale, New York: The Free Press.

1958 Gesammelte Politische Schfriten, Herausgegeben von Johannes Winckelmann. Tübingen: J.C.B. Mohr.

1961 General economic history, Translated by Frank Knight, New York: Collier Books.

1972 Wirtschaft und Gesellschaft, Tübingen: Mohr [1921].

1978 Economy and society: An outline of interpretive sociology. Edited by Guenther Roth and Claus Wittich. Berkeley: University of California Press.

1992 The Protestant Ethic and the Spirit of Capitalism. Translated by Talcott Parsons, Routledge, London, 1992 [1930].

1998 'Preliminary report on a proposed survey for a sociology of the press'. History of the Human Sciences, 11(2), 111-120.

2002 The Protestant Ethic and the 'Spirit' of Capitalism and Other Writings. Edited by Peter Baehr and Gordon C. Wells. London: Penguin.

2004 'Introduction to the Economic Ethics of World Religions' in Whimster, S. (ed.) The Essential Weber - A Reader (London: Routledge): 55-80.

Weischenberg S. 
2012 Max Weber und die Entzauberung der Medienwelt. Theorien und Querelen-eine andere Fachgeschichte, Wiesbaden: Springer. 